УДК 536.27

\title{
ПОРІВНЯЛЬНА ОЦІНКА ЕФЕКТИВНОСТІ СИСТЕМИ ТРАНСПОРТУВАННЯ ТЕПЛОНОСІЯ НА БАЗІ КОАКСІАЛЬНИХ ТРУБ
}

\author{
Демченко В.Г., канд. техн. наук, Дуняк О.В., Свтушенко О.В. \\ Інститут технічної теплофізики НАН Украӥни, вул. Желябова, 2а, Київ, 03680, Україна
}

Проведено порівняльний аналіз теплових, механічних та економічних характеристик теплових мереж - коаксіальної та традиційної двотрубної. Визначена оптимальна умова, при виконанні якої коаксіальна теплова мережа $є$ ефективнішою за традиційну.
Проведен сравнительный анализ тепловых, механических и экономических характеристик тепловых сетей - коаксиальной и традиционной двухтрубной. Определено оптимальное условие, при выполнении которого коаксиальная сеть является эффективнее традиционной.
Comparative analysis of thermal, mechanical and economic characteristics of thermal networks coaxial and the traditional two-pipe. The optimal condition under which performance coax network is more efficient than traditional.

Бібл. 11, рис. 4.

Ключові слова: теплові мережі, коаксіальні труби, коефіцієнт теплопередачі.

$b$ - відстань між осями труб;

$c-$ теплоємність;

$d$ - діаметр внутрішньої труби;

$D$ - діаметр зовнішньої труби;

$F$ - площа теплообміну;

$F_{c}$ - цільова функція;

$G$ - витрата;

$h$ - глибина залягання труб;

$K$ - коефіцієнт теплопередачі;

$N$ - потужність теплової енергії;

$\mathrm{Nu}$ - критерій Нусельта;

$P$ - повний опір;

$\operatorname{Pr}$ - критерій Прандтля;

$q$ - нормативна густина теплового потоку;

$Q$ - потужність механічної роботи;

$R$ - термічний опір;

$\mathrm{Re}$ - критерій Рейнольдса;

$S$ - витрати;

$t$ - температура;

$T$ - термін окупності;

$\alpha$ - коефіцієнт тепловіддачі;

$\varphi$ - коефіцієнт зволоження;

$\eta$ - коефіцієнт співвідношення потужностей ро-

боти до теплоти;

$\lambda$ - теплопровідність;

$\mu$ - динамічна в'язкість;

$v$ - кінематична в'язкість;

$\xi$ - коефіцієнт гідравлічного опору; $\rho-$ густина;

$\tau$ - число годин роботи обладнання на рік;

$\psi$ - коефіцієнт, що визначає додатковий опір подавального і зворотного трубопроводів;

$\omega$ - швидкість.

\section{Індекси нижні:}

0 - грунт;

1 - внутрішній;

2 - зовнішній;

1 in, 2 in - початковий параметр гарячого і холодного теплоносія відповідно;

1out, 2out - кінцевий параметр гарячого і холодного теплоносія відповідно;

eff-ефективний;

$e q v$ - еквівалентний;

exp - експлуатаційний;

gr - грунт;

ins - ізоляція;

$k$ - коаксіальний;

$k a p$ - капітальний;

$n$ - нормативний;

$m$ - монтажний;

$o p t$ - оптимальний;

Steel - стальний

PVC-C - полівінілхлорид;

$w$ - стінка. 


\section{Постановка задачі}

Нещодавно нами був запропонований i обгрунтований до впровадження новий спосіб транспортування теплоносія [1]. Він полягає у використанні системи коаксіальних труб з великим термічним опором розділяючої поверхні між гарячим та холодним теплоносіями (гарячий теплоносій у внутрішній трубі, холодний - у міжтрубному просторі), які рухаються протитоком.

На базі запропонованого способу шляхом розрахунків було встановлено: використання металевої внутрішньої труби призводить до швидкої втрати теплоти за рахунок вирівнювання температур гарячого та холодного теплоносія по довжині трубопроводу. Як наслідок, при довжині трубопроводів приблизно понад 300 п/м та діаметрах трубопроводів понад 350 мм доцільно використовувати трубопроводи 3 низькотеплопровідних полімерних матеріалів.

У даній роботі порівняємо ефективність коаксіальної теплової мережі 3 традиційною двотрубною, для чого виконаємо математичний опис двох систем з урахуванням втрат теплоти в навколишнє середовище, розрахуємо потужність механічної роботи, витраченої на перекачування теплоносіїв, та проведемо техніко-економічні розрахунки. Ключовою задачею $є$ визначення оптимальних умов, що нададуть перевагу у використанні коаксіальної теплової мережі для системи транспортування теплоносіїв порівняно зі стандартною двотрубною.

\section{Математичний опис та аналіз}

Основні припущення математичної моделі теплових мереж (ТМ):

1) Для традииійної системи ТМ: теплоносії рухаються $з$ однаковою витратою; теплофізичні властивості приймаються при середніх температурах теплоносіїв;

2) Для коаксіальної системи ТМ: гарячий теплоносій рухається у внутрішньому трубному просторі, холодний - у міжтрубному; прийнято, що матеріал внутрішньої труби - хлорований полівінілхлорид (PVC-C), матеріал зовнішньої труби - сталь.
Для обох систем розглядається стаціонарний режим руху теплоносіїв; втрати теплоти у споживача $\epsilon$ однаковими; теплоізоляція ТМ пінополіуретан ППУ; спосіб прокладки труб безканальний.

Для проведення розрахунків i побудови розрахункових кривих розподілення температур гарячого $t_{1 s}, t_{1 k}$ та холодного теплоносіїв $t_{2 s}$, $t_{2 k}$, $(s-$ стандартна TM, $k$ - коаксіальна ТМ) по довжині труби $x$ з урахуванням втрат теплоти в навколишнє середовище використовувались такі дані: теплоносій - вода; початкова температура гарячого теплоносія $\left[{ }^{\circ} \mathrm{C}\right] t_{1 \text { in } s}=t_{1 \text { in } k}=95$; початкова температура холодного теплоносія $\left[{ }^{\circ} \mathrm{C}\right]$ $t_{2 i_{-} s}=70, t_{2 i n_{-} k}=65$; витрата холодного і гарячого теп̆лоносіїв однакова $G_{1}=G_{2}$; теплопровідність сталі $[\mathrm{BT} / \mathrm{M} \cdot \mathrm{K}] \lambda_{\text {Steel }}=47$ (традиційна TM); теплопровідність хлорованого полівінілхлориду (PVC-C) $[\mathrm{BT} / \mathrm{M} \cdot \mathrm{K}] \lambda_{P V C-C}=0,137$ [2]; внутрішній діаметр [м] $d_{1 s}=d_{1 k}=d_{1}=0,264$; зовнішній діаметр [м] $d_{2 s}^{-}=d_{2 k}=d_{2}=0,273$; внутрішній діаметр зовнішньої труби [м] $D_{1 k}=D_{1}=0,326$, $D_{1 s}=d_{1}=0,264$; зовнішній діаметр зовнішньої трубби [м] $D_{2 k}=D_{2}=0,335, D_{2 s}=d_{2}=0,273$.

Теплофізичні властивості теплоносіїв при обраній середній температурі гарячого теплоносія $\overline{t_{1 k}}=92^{\circ} \mathrm{C}$, холодного теплоносія $\overline{t_{2 k}}=68^{\circ} \mathrm{C}$ та температурі стінки $\overline{t_{w}}=75^{\circ} \mathrm{C}[3]$ (припускається, що вихідна температура гарячого i холодного теплоносіїв не перевищує $t_{1 o u t k}=90{ }^{\circ} \mathrm{C} \mathrm{i}$ $t_{2 \text { out } k}=70{ }^{\circ} \mathrm{C}$ відповідно): динамічна в'язкість [Пॅа $\cdot \mathrm{c}]: \mu_{1 k}=307 \cdot 10^{-6}, \mu_{2 k}=422 \cdot 10^{-6}$, кінематична в'язкість $\left[\mathrm{M}^{2} / \mathrm{c}\right]: v_{1 \_k}=0,318 \cdot 10^{-6}, v_{2 \_k}=0,43 \cdot 10^{-6}$; густина $\left[\kappa г / \mathrm{M}^{3}\right]:{ }^{-} \rho_{1 k}=961,3, \rho_{2 k}=979,2$; теплопровідність $[\mathrm{BT} /(\mathrm{M} \cdot \mathrm{K})]: \quad \lambda_{1 k}=0,681$, $\lambda_{2 k}=0,666$;теплоємність ${ }^{1-k}[$ Дж/(кг·К)]: $c_{1 k}^{2-k}=4,21 \cdot 10^{3}, \quad c_{2 k}=4,185 \cdot 10^{3} ;$ критерій Прандтля для стінкй: $\operatorname{Pr}_{w}=2,38$. В межах температур $70 \ldots 95{ }^{\circ} \mathrm{C}$ теплофізичні властивості води не мають великих розходжень, тому інші вибрані значення середніх температур теплоносіїв неістотно вплинуть на остаточний результат.

Для визначення кінцевої температури гарячого теплоносія $t_{\text {lout } k}$ для коаксіальної ТМ скористаємось відомою 3 теорії розрахунку теплообмінників [4] формулою: 


$$
t_{1 \_k}=t_{1 i n}-\left(t_{1 i n}-t_{2 i n}\right) \frac{1-\exp \left[-\frac{K_{1 \_k} \cdot F_{1 \_k}}{C_{1}}\left(1-\frac{C_{1}}{C_{2}}\right)\right]}{1-\frac{C_{1}}{C_{2}} \exp \left[-\frac{K_{1 \_k} \cdot F_{1 \_k}}{C_{1}}\left(1-\frac{C_{1}}{C_{2}}\right)\right]} .
$$

Для холодного теплоносія кінцеву температуру $t_{2 \text { out } k}$ розрахуємо за [4] аналогічною формулою, але врахуємо втрати теплоти в навколишнє середовище (грунт), тобто:

$$
t_{\text {out } 2_{-} k_{-} \text {loss }}(x)=t_{2 \text { in }}+\left(t_{\text {lin }}-t_{2 \text { in }}\right) \frac{C_{1}}{C_{2}} \frac{1-\exp \left[-\frac{K_{1 \_k} \cdot F_{1 \_} k}{C_{1}}\left(1-\frac{C_{1}}{C_{2}}\right)\right]}{1-\frac{C_{1}}{C_{2}} \exp \left[-\frac{K_{1 \_k} \cdot F_{1 \_} k}{C_{1}}\left(1-\frac{C_{1}}{C_{2}}\right)\right]}-\Delta t_{\text {lost }} \text {. }
$$

Втрати $\Delta t_{\text {lost }}$ знайдемо із рівнянь теплопередачі та теплового потоку холодного теплоносія:

$$
\Delta t_{\text {lost }}=\frac{K_{2_{-} k} \cdot F_{2_{-} k} \cdot\left(\bar{t}_{2_{-} k}-t_{0}\right)}{G_{2} \cdot c_{2_{-} k}},
$$

де $G_{2}-$ витрата холодного теплоносія, кг/с, $G_{2}=G_{1}=\rho_{1} \cdot \omega_{1} \cdot \frac{\pi d_{1}^{2}}{4}, \quad \omega_{1}-$ швидкість руху гарячоготеплоносія, $\omega_{1}=1,5 \mathrm{~m} / \mathrm{c}[5] ; F_{2 k}-$ поверхня теплопередачі, $\mathrm{M}^{2} ; F_{2 \_}=\pi D_{i n s-k} x, x-$ довжина трубопроводу, м; $D_{\text {ins } k}-$ діаметр ізольованої поверхні, м; $t_{2 k}-$ середня температура холодного теплоносія, ${ }^{0} \mathrm{C} ; t_{0}$ - температура грунту на глибині залягання ТM, $t_{0}=5{ }^{0} \mathrm{C}$ [6]; $K_{2 k}-$ коефіцієнт теплопередачі системи «труба в трубі», Вт/ $\left(\mathrm{M}^{2} \cdot \mathrm{K}\right)$; $K_{2_{-} k}=\frac{1}{R_{k}} ; \quad R_{k}-$ сумарний термічний опір коаксіальної труби, $\left(\mathrm{M}^{2} \cdot \mathrm{K}\right) / \mathrm{B}$.

Сумарний термічний опір коаксіальної труби визначається за формулою:

$R_{k}=R_{1 \_k}+R_{w 1 \_k}+R_{2 \_k}+R_{w 2 \_k}+R_{\text {ins } \_k}+R_{0}$,

де $R_{1 k}, R_{2 k}, R_{0}, R_{w 1 k}, R_{w 2 k}, R_{\text {ins } k}-$ термічні опори: тепловіддачі від гарячого теплоносія до теплообмінної поверхні, від теплообмінної поверхні до холодного теплоносія, від теплообмінної поверхні до оточуючого середовища (грунту), теплопровідності стінки внутрішньої, зовнішньої труб та теплоізоляції, $\left(\mathrm{M}^{2} \cdot \mathrm{K}\right) / \mathrm{B}$.

Термічні опори знайдемо за формулами:

$$
R_{1_{-} k}=\frac{1}{\pi \alpha_{1 \_} d_{1}} ; \quad R_{w 1_{-} k}=\frac{1}{2 \pi \lambda_{w 1} k} \ln \frac{d_{2}}{d_{1}} ;
$$

$$
\begin{aligned}
& R_{2_{-} k}=\frac{1}{\pi \alpha_{2_{-} k} D_{1_{-} k}} ; R_{w 2_{-} k}=\frac{1}{2 \pi \lambda_{w 2_{-} k}} \ln \frac{D_{2_{-} k}}{D_{1_{-} k}} ; \\
& R_{\text {ins }_{-} k}=\frac{1}{2 \pi \lambda_{\text {ins }}} \ln \frac{D_{\text {ins }} k}{D_{2_{-} k}} ; \quad R_{0}=\frac{1}{\alpha_{0}},
\end{aligned}
$$

де $\alpha_{1 k}, \alpha_{2 k}, \alpha_{0}-$ коефіцієнти тепловіддачі від гарячого теплоносія до теплообмінної поверхні, від теплообмінної поверхні до холодного теплоносія та від теплообмінної поверхні до оточуючого середовища (грунту) відповідно, Вт/ $\mathrm{M}^{2} \cdot \mathrm{K} ; \lambda_{w 1}$, $\lambda_{w 2}, \lambda_{\text {ins }}-$ теплопровідність матеріалів труб та теплоізоляції відповідно, Вт/м·К.

Оскільки система коаксіальних труб знаходиться в безканальній прокладці, тому визначається за формулою [7].

$\lambda_{\text {ins }}=\lambda \cdot \varphi$,

де $\lambda$ - теплопровідність сухого матеріалу теплоізоляції, Вт/м $\cdot \mathrm{K}_{i n s}=0,05 \mathrm{BT} / \mathrm{M} \cdot \mathrm{K} \quad$ [7]; $\varphi$ - коефіцієнт зволоження, що враховує теплопровідність та приймається залежно від типу ізоляційного матеріалу та типу грунту $\varphi=$ $1,05[7]$.

Зовнішній діаметр шару теплоізоляції визначимо із формули [8]:

$\ln \frac{D_{\text {ins_k }} k}{D_{2_{-} k}}=\frac{2 \pi \lambda_{\text {ins }} \lambda_{g r}}{\lambda_{g r}-\lambda_{\text {ins }}}\left(\frac{\left(\bar{t}_{2} k\right.}{\left.-t_{0}\right) k_{\text {red }}}-\frac{\ln \frac{4 h}{D_{2_{-} k}}}{2 \pi \lambda_{g r}}\right)$,

де $\lambda_{g r}-$ теплопровідність грунту, $\lambda_{g r}=1,74 \mathrm{BT} /$ $\mathrm{M}^{\cdot} \mathrm{C}^{g r}[5] ; q_{2 k}-$ нормативна густина теплового по- 
току зворотного трубопроводу, $q_{2 \_}=79$ м [9]; $t_{2 \_}-$середньорічна температура зворотного трубопроводу, для визначення теплових втрат приймається $\bar{t}_{2} k=50{ }^{0} \mathrm{C}[5] ; h-$ глибина залягання осі трубопроводу, м, $h=1,5$ м [6]; $k_{\text {red }}$ - коефіцієнт, що враховує втрати теплоти конструктивними елементами мережі, $k_{\text {red }}=1,5$ [8].

При підземній безканальній прокладці теплота 3 поверхні ізольованого шару передається безпосередньо грунту, тобто $1 / \alpha_{0}=R_{g r}$. Значення $R_{g r}$ знаходиться за формулою [9]:

$R_{g r}=\frac{1}{2 \pi \lambda_{g r}} \ln \left[\frac{2 h}{D_{i n s}}+\sqrt{\left(\frac{2 h}{D_{i n s}}\right)^{2}-1}\right]$

Формулу (8) можна представити у вигляді [10]:

$$
R_{g r}=\frac{1}{2 \pi \lambda_{g r}} \ln \frac{4 h}{D_{i n s}} .
$$

Оскільки коефіцієнт тепловіддачі від гарячого та холодного теплоносіїв до теплообмінних поверхонь значно більший за коефіцієнт тепловіддачі від зовнішньої поверхні теплоізоляції до оточуючого середовища, тобто $\alpha_{1}>>\alpha_{0}$ та $\alpha_{2}>>\alpha_{0}$, то термічними опорами $R_{1}$, $R_{2}$ можна знехтувати. Так само можна знехтувати і термічними опорами $R_{w 2}, R_{w 1}$ у зв'язку 3 тим, що $\lambda_{i n s}, \lambda_{g r}>>\lambda_{w 1 k k} \lambda_{w 2 k}$. Тому формула (4) спрощується до вигляду [10]:

$R_{k}=R_{\text {ins }}+R_{g r}$.

Для визначення кінцевих температур гарячого та холодного теплоносіїв $t_{1 \text { outs } s}$ та $t_{20 u t s}$ для традиційної ТМ скористаємось формулами [7]:

$t_{1,2 \text { out } \_s}=t_{0}+\left(t_{1,2 \text { in_s } s}-t_{0}\right) \exp \left(-\frac{K_{1,2 \_s} F_{s}}{G_{1,2} c_{1,2} s}\right)$

де $F_{s}$ - поверхня теплопередачі, $\mathrm{M}^{2}, F_{s}=\pi d_{\text {ins } s} x$; $x$ - довжина трубопроводу, м; $d_{i n s s}-{ }^{s}$ діамётр ізольованої поверхні, м; $K_{1,2 s}{ }^{-}$коефіцієнт теплопередачі, $\quad$ Вт/( $\left.{ }^{2} \cdot \mathrm{K}\right), \quad{ }_{1,2} K_{1,2 \_}=1 / R_{1,2 \_}$; $R_{1,2}$ - термічні опори подавального і зворотного трубопроводів відповідно, $\left(\mathrm{M}^{2} \cdot \mathrm{K}\right) / \mathrm{BT} ; c_{1,2 s}-$ теплоємність гарячого i холодного теплоносіїв стандартної ТМ, $c_{1 s}=4211$ Дж/(кг К $)$, $c_{2 s}=4187$ Дж/(кг·К) [3].

Зовнішній діаметр шару теплоізоляції подавального і зворотного трубопроводів визначимо iз формули [6]:
$\ln \frac{d_{\text {ins } s}}{d_{1,2 \_s}}=\frac{2 \pi \lambda_{\text {ins }} \lambda_{g r}}{\lambda_{g r}-\lambda_{\text {ins }}}\left(\frac{\left(t_{1,2 \_s}-t_{0}-q_{1,2 \_s} R_{0}\right) \cdot k_{r e d}}{q_{1,2 \_s}}-\frac{\ln \frac{4 h}{d_{1,2 \_} s}}{2 \pi \lambda_{g r}}\right),(11)$

де $q_{1,2 s}$ - нормативна густина теплового потоку подавӓльного і зворотного трубопроводів, $q_{1 \_s}=$ $83 \mathrm{BT} / \mathrm{M}, q_{2 s}=63 \mathrm{BT} / \mathrm{м}[9] ; \bar{t}_{1,2} k-$ середньорічна температура подавального $\mathrm{i}$ зворотного трубопроводів, для визначення теплових втрат приймається $\bar{t}_{1 \_s}=65{ }^{0} \mathrm{C}, \bar{t}_{2 \_s}=50{ }^{0} \mathrm{C}[5] ; R_{0}-$ фактор термічного опору взаємного впливу трубопроводів при двотрубній прокладці,

$R_{0}=\frac{1}{2 \pi \lambda_{g r}} \ln \sqrt{1+\left(2 \frac{h}{b}\right)^{2}} ;$

$b$ - відстань між осями трубопроводів при двотрубній прокладці, $b=0,75$ м [7].

У зв'язку 3 нехтовно малими величинами термічного опору теплоносіїв та стінок трубопроводів $R_{1,2 \_s}$ Знайдемо за формулою:

$R_{1,2 \_s}=R_{\text {ins }}+R_{\mathrm{gr}}+\psi_{1,2} R_{0}$,

де $\psi_{1,2}-$ коефіцієнти, що визначають додатковий термічний опір подавального і зворотного трубопроводів:

$$
\psi_{1,2}=\frac{\left(\Delta t_{2,1_{-} s}-t_{0}\right) \frac{1}{2 \pi \lambda_{\text {ins }}} \ln \left(\frac{d_{\text {ins }}}{d_{2}}\right)-\left(\Delta t_{1,2_{-} s}-t_{0}\right) R_{0}}{\left(\Delta t_{1,2 \_s}-t_{0}\right) \frac{1}{2 \pi \lambda_{\text {ins }}} \ln \left(\frac{d_{\text {ins }}}{d_{2}}\right)-\left(\Delta t_{2,1_{-} s}-t_{0}\right) R_{0}},
$$

де $\Delta t_{1,2 s}-$ середня температура гарячого і холодного теплоносіїв відповідно, ${ }^{0} \mathrm{C}$.

Побудуємо та порівняємо графіки зміни температур теплоносіїв по довжині трубопроводів для коаксіальної і традиційної ТМ.

При побудові графіків виконувалась умова, що $t_{1 \text { outss }}-t_{2 \text { in s }}=t_{\text {lout } k}-t_{2 \text { in_k } k}$, тобто коаксіальна $\mathrm{i}$ традиційна ТМ віддавали споживачу однакову кількість теплоти.

Для аналізу графіку (рис. 1) визначимо, яку кількість теплоти необхідно підвести до холодного теплоносія при використанні як традиційної, так і коаксіальної ТМ, щоб догріти його до вихідної температури гарячого:

$Q_{s, k}=\frac{t_{1 i n \__{-}, k}-t_{2 o u t_{-} s, k}}{G_{1} c_{s, k}}$.

Маємо $Q_{s}=7,611 \cdot 10^{-5} \mathrm{~B}$, $Q_{k}=7,445 \cdot 10^{-5} \mathrm{BT}$. 


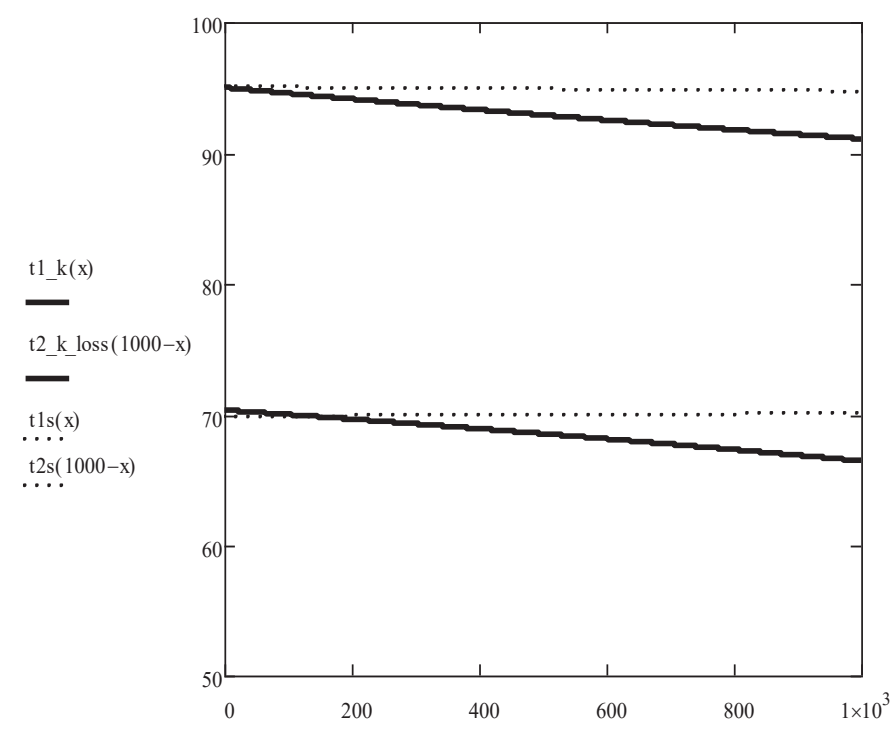

Рис. 1. Графіки залежнності температур гарячого $\left(t_{1, s_{1},} t_{1}\right)$ i холодного $\left(t_{2,}, t_{2 \_}\right)$ теплоносіӥв від довжини трубопроводів коаксіальйої та традиційної ТМ.

Отже, аналізуючи графіки рис. 1, можна зробити висновок, що за заданих однакових початкових умов для двох ТМ при використанні коаксіального трубопроводу необхідно затратити менше теплової енергії для нагріву холодного теплоносія до початкової температури гарячого. Це, в свою чергу, призводить до економії витрати палива при генеруванні теплової енергії. При цьому у разі використання коаксіальної ТМ, порівняно зі стандартною, до споживача буде надходити теплоносій з меншою температурою.

\section{Визначення витрат механічної роботи на прокачку теплоносіївдля двох ТМ та вирішення оптимізаційної задачі}

Сумарну потужність насосів на прокачку теплоносіїв у коаксіальній ТМ визначимо за формулою [11]:

$N_{k}=N_{1 \_k}+N_{2 \_k}$

$N_{1,2_{-} k}=\frac{G_{1,2} \Delta P_{1,2_{-} k}}{\rho_{1,2_{-} k}}$,

де $N_{1,2 k}-$ потужність подавального і зворотного трубопроводів; $\Delta P_{1,2 k}-$ повний опір при русі теплоносія через трубопровід,

$$
\begin{aligned}
& \Delta P_{1,2}=\zeta_{1,2 \_k} \frac{x}{d_{e f f 1,2-k}} \frac{\rho \omega_{1,2}^{2}}{2} ; \\
& \quad \xi_{1,2 \_k}-\text { коефіцієнт гідравлічного опору, } \xi_{1,2 \_k}=
\end{aligned}
$$

$=0,316 / \mathrm{Re}^{0,25}$ для турбулентного режиму руху теплоносіїв; $\mathrm{Re}_{1,2}$ - критерій Рейнольдса $\mathrm{y}$ трубному і міжтрубному просторі відповідно; $d_{\text {eff } 1,2 k}$-ефективнийдіаметр, $d_{\text {eff } 1 \_k}=d_{1}, d_{\text {eff } \_k}=D_{1 \_\mathrm{k}}-d_{2}$.

Оскільки у традиційній ТМ трубопроводи мають такі самі геометричні розміри та витрату теплоносіїв, як і подавальний трубопровід коаксіальної ТМ, то сумарна потужність насосів визначається за формулою:

$N_{s}=N_{1 \_s}+N_{2 \_s}=2 N_{1 \_k}$.

Побудуємо графіки співвідношення потужностей роботи і теплоти, підведеної до двох транспортних систем $n(x)=N(x) / Q(x)$.

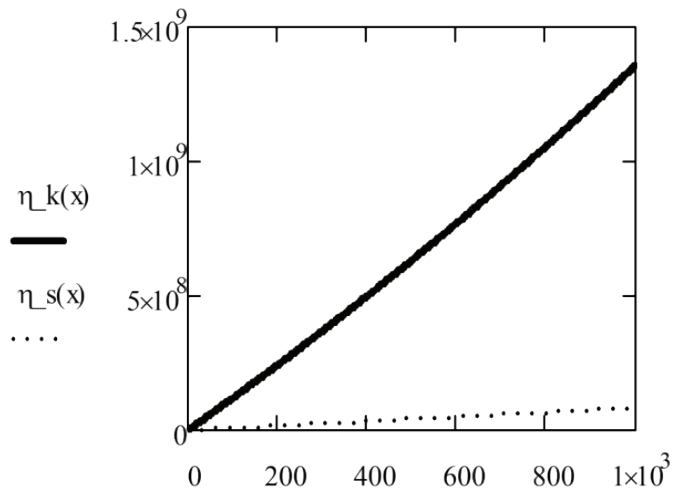

Рис. 2. Графіки співвідночення потужсностей механічної роботи та теплоти, підведеної до коаксіальної $\eta_{k}(x)$ та традиційної $\eta_{s}(x)$ TM. 
Аналізуючи графік (рис. 2) видно, що при заданих геометричних параметрах ТМ співвідношення роботи і теплоти, підведеної до коаксіальної ТМ, значно зростає по довжині трубопроводів порівняно $з$ традиційною, тобто коаксіальна ТМ потребує значно більших витрат механічної роботи на прокачку теплоносіїв. Отже, з даного факту можна зробити висновок, що за вибраних довільно геометричних параметрах коаксіальної ТМ вона працює менш ефективно у порівнянні з традиційною двотрубною. Тому спробуємо вирішити оптимізаційну задачу, що полягає у мінімізації значення механічної роботи, яку необхідно витратити на прокачку теплоносія у коаксіальній ТМ.

Пропонуємо внутрішній діаметр зовнішньої труби $D$ коаксіальної ТМ зробити невідомою величиною, та знайти ту умову, при якій $\eta_{k}(x)<\eta_{s}(x)$.

Приймемо, що поперечні перерізи трубного і міжтрубного простору однакові, при цьому повинна виконуватись рівність:

$$
D_{1 \_k}=\sqrt{d_{1 \_k}^{2}+d_{2 \_k}^{2}} \text {. }
$$

На базі проведених розрахунків побудуємо нові графіки співвідношення роботи і теплоти $\eta_{k}\left(x, D_{1 \_}\right)$та $\left.\eta_{s}()_{x}\right)$ з урахуванням умови (18).

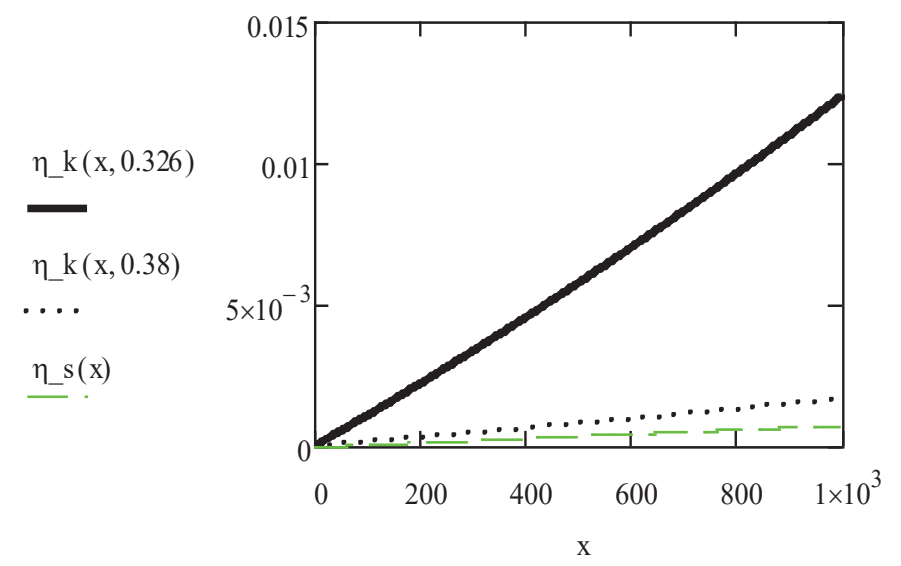

Рис. 3. Графіки співвідношення механічної роботи та теплоти підведеної до коаксіальної та традиційної ТМ.

3 графіку (рис. 3) видно, що при виконанні умови (18) співвідношення $\eta_{k}\left(x, D_{1 k}\right)$ значно наблизилось до $\eta_{s}(x)$, тобто витрати механічної ро- боти на прокачку теплоносія в коаксіальній ТМ зменшуються по довжині зі збільшенням поперечного перерізу міжтрубного простору.

Перетворимо формулу (18) та визначимо геометричний фактор $k$ :

$$
k=\frac{D_{1 \_k}}{\sqrt{d_{1 \_}^{2}+d_{2 \_}^{2} k}} .
$$

Шляхом довільного підбору геометричного фактору $k$, визначимо його критичне значення, при якому традиційна та коаксіальна теплові мережі будуть тотожними. Це значення $k=1,122$. При $k>1,122$ витрати механічної роботи на прокачку теплоносія у коаксіальній ТМ є меншими за традиційну, тобто співвідношення $\eta_{k}(x)<\eta_{s}(x)$. Тобто варіюючи геометричними параметрами зовнішньої труби коаксіальної ТМ можна досягти іï суттєвої ефективності у порівнянні 3 традиційною двотрубною.

Для внесення більшої ясності у те, чи вигідна у своєму використанні коаксіальна ТМ порівняно зі стандартною, виконаємо ще й технікоекономічний розрахунок для обох ТМ.

\section{Техніко-економічний розрахунок коаксіальної $i$ традиційної TM}

Цільова функція включає капітальні та експлуатаційні витрати [11]:

$$
F_{c}=\frac{S_{k a p}}{T_{n}}+S_{\text {exp }}
$$

де $S_{k a p}$ - капітальні витрати, грн.; $T_{n}$ - нормативний термін окупності капітальних витрат, $S \exp$ - експлуатаційні витрати, грн.

Капітальні витрати:

- для коаксіальної ТМ:

$S_{k a p \_k}=\left(S_{1 \_k}+S_{2 \_k}+S_{\text {ins_k }}\right) \cdot\left(1+\alpha_{t}\right)+S_{m \_k}$,

де $S_{1, k}, S_{2 k}, S_{\text {ins }}$ - капітальні витрати на внутрішню, зовнішню труби та теплоізоляцію відповідно, грн.; $S_{m_{k} k}-$ вартість монтажних робіт, грн.; $\alpha_{t}-$ транспортні витрати, $\alpha_{t}=0,15$ :

$S_{1 \_k}=S_{P V C-C} \cdot V_{1} \cdot \rho_{P V C}, \quad S_{2 \_k}=S_{S t e e l} \cdot V_{2} \cdot \rho_{\text {Steel }}$, $S_{\text {ins } \_k}=S_{\text {ins }} \cdot V_{\text {ins_k }} \cdot \rho_{\text {ins }}, \quad S_{m_{-} k}=S_{D N 200} \cdot x$,

де: $S_{P V C-C}, \quad S_{S t e e l}, \quad S_{i n s}, \quad-\quad$ вартість матеріалів внутрішньої, зовнішньої труб та теплоізоляції, $S_{P V C-C}=45$ грн./кг, $S_{\text {Steel }}=10$ грн./кг, $S_{\text {ins }}=100$ 
грн./кг; $S_{D N 200}-$ вартість монтажу 1м.п. ТМ при безканальній прокладці DN300, $S_{D N 300}=1200$ грн.; $\rho_{\text {PVC-C }}, \rho_{\text {Steel }}, \rho_{\text {ins }}-$ густина матеріалів внутрішньої, зовнішньої труб та теплоізоляції, $\rho_{P V C}=1400 \mathrm{\kappa} / \mathrm{M}^{3}$, $\rho_{\text {Steel }}=7800 \kappa \Gamma / \mathrm{M}^{3}, \rho_{\text {ins }}=60 \mathrm{\kappa} / \mathrm{M}^{3} ; V_{2} V_{\text {ins }}-$ об'єм використаного матеріалів внутрішньої, зовнішньої труб та теплоізоляції, $\mathrm{M}^{3}$ :

$V_{1}=\frac{\pi\left(d_{2}^{2}-d_{1}^{2}\right)}{4} x, V_{2}=\frac{\pi\left(D_{2}^{2}-D_{1}^{2}\right)}{4} x$,

$V_{\text {ins_k }}=\frac{\pi\left(D_{\text {ins }}^{2}-D_{2}^{2}\right)}{4} x$.

- для традиційної ТМ:

$S_{\text {kap_s }}=\left(2 S_{s}+2 S_{\text {ins_s }}\right) \cdot\left(1+\alpha_{t}\right)+S_{m_{-} s}$

де $S_{s}, S_{i n s s}-$ капітальні витрати на трубопровід та теплоізоляцію відповідно, грн.; $S_{m s}-$ вартість монтажних робіт, грн.; $\alpha_{t}$-транспортні витрати, $\alpha_{t}=0,15$ :

$S_{s}=S_{\text {Steel }} V_{1} \rho_{\text {Steel }}, S_{\text {ins_s }}=S_{\text {ins }} V_{\text {ins_s }} \rho_{\text {ins }}, S_{m_{-} k}=S_{\text {DN200 }} \cdot x$,

де $S_{D N 200}$ - вартість монтажу 1м.п. ТМ при безканальній прокладці DN200; $S_{D N 200}=960$ грн; $V_{\text {ins } s}-$ об'єм використаного матеріалу теплоізоляції, $\mathrm{M}^{3}$ :
$V_{\text {ins_s }}=\frac{\pi\left(d_{\text {ins }}^{2}-d_{2}^{2}\right)}{4} x$.

Експлуатаційні витрати включають в себе: витрати на прокачку теплоносіїв по ТМ, витрати на ремонт і обслуговування тощо.

Витрати на прокачку теплоносія визначимо за формулою:

- для коаксіальної ТМ:

$S_{\text {exp } \_k}=N_{k} \cdot K_{e n} \cdot \tau$,

де $K_{e n}-$ вартість енергії на приведення в дію допоміжного обладнання, $K_{e n}=1,91$ грн./(кВт. год); $\tau$ - число годин роботи обладнання на рік, $\tau=4320$ год.

- для традиційної ТМ:

$S_{\text {exp } s}=N_{s} \cdot K_{e n} \cdot \tau$.

Побудуємо графік залежності $F_{c}(x)$ для коаксіальної та традиційної ТМ.

На рис. 4 показано, що при заданій умові для коаксіальної ТМ $k=1,122$ графіки цільової функції коаксіальної і традиційної ТМ співпадають, тобто вони $є$ однаково ефективними. При $k>1,122$ ефективно працездатною $\epsilon$ коаксіальна ТМ, при $k<1,122$ - традиційна двотрубна тепломережа.

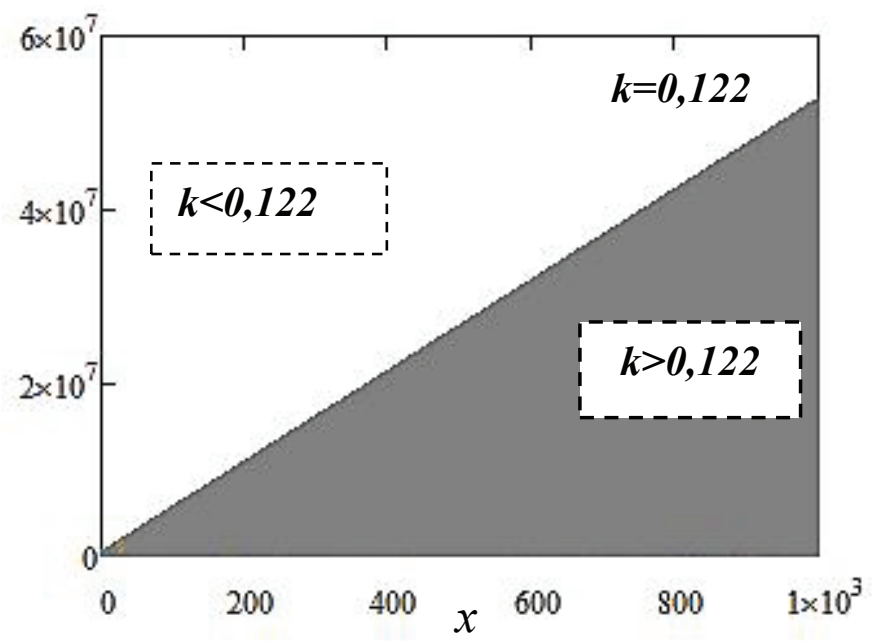

Рис. 4. Графік залежності загальних витрат коаксіальної і традиційної ТМ по довжині.

\section{Висновки}

1. Запропонована нова конструкція коаксіального трубопроводу може ефективно вирішити проблеми транспортування теплоносія при мінімальних капіталовкладеннях. Використання коаксіальних труб призводить до значно- го зменшення габаритних розмірів тепломережі, відчутного зменшення вартості будівельномонтажних робіт, суттєвого зменшення тепловтрат та компенсації теплових навантажень.

2. Проведений математично-економічний аналіз показує, що використання коаксіальних 
ТМ може мати великі перспективи до впровадження, однак слід враховувати, що коаксіальна TM потребує більших витрат роботи на перекачку теплоносія, а отже експлуатаційних витрат.

3. Запропоновано введення геометричного фактору $k$, варіюючи яким можна робити коаксіальну ТМ ефективнішою за традиційну двотрубну.

\section{ЛІТЕРАТУРА}

1. Ракитянська Н.А., Свтушенко О.В., Дуняк O.B., Демченко В.Г. Перспектива використання коаксіальних труб як новий спосіб транспортування теплоносія в теплових мережах // Науковий журнал «Промышленная теплотехника» - 2016. №1.

2. Журнал «Монтаж+Технологія» №7 / за ред. ТОВ «Форум Інвест», 2010. - 24 с.

3. Варгафтик Н.Б. Справочник по теплофизическим свойствам газов и жидкостей.

4. Ильченко O.T. Тепло и массообменные аппараты ТЭС и АЭС: Учеб.пособие. - К.: Вища шк, 1992. - 207 c.
5. СНиП 41-02-2003 Тепловые сети.

6. Николаев A.A. Справочник проектировщика.

7. СНиП 41-03-2003 Тепловая изоляция оборудования и трубопроводов

8.TCH 23-337-2002 Тепловая изоляция оборудования и трубопроводов. - Свердловская область, Екатеринбург, 2002.

9. РД 153-34.0-20.523-98 Часть 2 Методические указания по составлению энергетической характеристики водяных тепловых сетей по показанию «тепловые потери».

10. Тарасевич Е.И. Особенности теплового расчета водяных тепловых сетей. // Научный журнал ISSN 2070-7428 Современные проблемы науки и образования - 2014. - № 6.

11. Андрижиевский А.А., Веремеева О.Н., Трифонов А.Г. Использование программного пакета MATLAB для оптимизации теплообменника «труба в трубе» Журнал //Exponenta. pro. Математика в приложениях. - 2004. -№1(5). 
COMPARATIVE EVALUATION Of THE EFFECTIVENESS Of THE SYSTEM OF TRANSPORT Of COOLANT BASED ON COAXIAL TUBES

Demchenko V.G. , Dunyak O.V., Yevtushenko O.V.

Institute of Engineering Thermophysics of the National Academy of Sciences of Ukraine, vul. Zhelyabova, 2a, Kyiv, 03680, Ukraine

The article spent a comparative analysis of the efficiency and standard and traditional pipe heating systems. For both heating systems performed mathematical calculations of coolant temperature distribution along the length of the network with taking into account the loss of heat to the environment, designed power mechanical works spent on pumping fluids and executed technical and economic calculations, bringing found optimum condition in the performance of which the objective function of the standard thermal network is greater in comparison with coaxial that gives an advantage to the latter for transporting fluids.

References 11, figures 4.

Key words: heat networks, coaxial tubes, the coefficient of heat transfer.

1. Rakityanska N.A., Yevtushenko O.V., Dunyak
O.V., Demchenko V.G. Perspective use coaxial tube as a new way of transportation in thermal networks // Promyshlennaya teplotekhnika. - 2016. - № 1 .

2. Magazine "Assembly + Technology "No. 7/Ed. Forum invest LLC. $-2010 .-24 \mathrm{p}$.

3.Vargaftik N.B. Reference book on thermophysical properties of gases and liquids.

4. Ilchenko O.T. Warm and mass interchanger's apparatus TÈS and NPP.Kyiv: Higher school, 1992. - $207 \mathrm{p}$.

5. SNIP 41-02-2003. Heating nets.

6. Nikolaev V.A. Reference book of designer .

7. Law 41-03-2003 Thermal isolation of equipment and pipelines.

8. TSN 23-337-2002 Thermal isolation of equipment and pipelines. Yekaterinburg. 2002.

9. $R D$ 153-34.0-20.523-98 Part 2.Methodical pointing on drafting of power description of aquatic thermal networks on a testimony "thermal losses".

10. Tarasevych E.K. Features of thermal calculation of aquatic thermal networks. // Scientific magazine ISSN 2070-7428 Modern problems of science and education. - 2014.- № 6.

11. Andrizhievskij A.A., Veremeeva O.N, Trifonov A.G. Using MATLAB software package for the optimization of heat exchanger "pipe-inpipe" //Exponenta. pro. Mathematika V prilozheniyach. - 2004. - № 1 (5).

Получено 15.06.2016

Received 15.06.2016 